\title{
Creative Accounting: A Short Literature Review
}

\author{
Lenka Strakova and Katarina Zvarikova
}

\author{
University of Zilina, Faculty of Operation and Economics of Transport and Communications, Univerzitna 1, 010 \\ 26 Zilina, Slovakia \\ *Corresponding author. Email: lenka.strakova@fpedas.uniza.sk
}

\begin{abstract}
In the professional literature, creative accounting is understood as legitimate, which means that it is not illegal to the extent that it does not violate the legislation of the country. Although it is a numbers game that can mislead internal or external users of financial statements, in some cases it can help protect a business from bankruptcy or other adverse conditions. This paper aims to represents creative accounting through various studies by authors dealing with the issue. The studies included in this paper provide insight into creative accounting, taking into account its origins, motives, tools, ethical approach, and its impact on financial reporting or the task of auditors in exposing creative techniques. This paper provides an overview of the period from 2000 to 2021 . The study presented in this paper is an exploratory one, based on secondary sources of information.
\end{abstract}

Keywords: Creative accounting, Financial information, Financial statement, Managers, Investors.

\section{INTRODUCTION}

Accounting is the basic pillar of every business unit in the business environment [1]. It provides important financial information [2] that is used in their work not only by the business unit's managers themselves [3] but also by other external entities that have decision-making authority outside the entity's business environment [4]. Financial information is contained in the financial statements of each entity [5] and is intended to mirror correct company's accounting data do not only internal but also external entities [6]. In practice, however, there is a problem that may cause a conflict of interest between stakeholders [7], as one party representing investors expects and requests correct and truthful financial information [8] that it uses in its decision- making power [9], but the other party, represented by specific business units, tries to attract more investors to their business environment, using creative accounting to combat growing competition and adverse economic conditions. In the literature, we find several different views on the issue of creative accounting, which can be understood as modification of accounting reports to adjust achieving data in the desired results or as a process in which economic transactions are carried out to achieve a more favorable result in accounting.

\section{METHODOLOGY}

This contribution is focused on providing a short chronological literature review of creative accounting using in a business environment. The study presented in this paper is an exploratory one, based on secondary sources of information. The secondary sources include published journals and conferences. We provide a chronological overview of the creative accounting literature over the years 2000-2021.

\section{RESULTS AND DISCUSSION}

The research area of the author Kanda was focused on using the technic of creative accounting in Indian companies which is called window dressing. His research was focused on audit firms and commercial companies and found that the analyzed subjects used the creative technique of window dressing to attract investors to their business environment and reduce their tax liability [10]. Another author Baralexis focused their research on auditors and accountants in Greece and the results of his research have shown that creative accounting is widely used in the Greek country, with its users preferring more legitimate creative techniques compared to illegitimate creative accounting techniques [11]. Sen et al. focused their research on companies in Bangladesh and based on 
the Questionnaire survey they found out that $82 \%$ of respondents replied that creative accounting has also been used in Bangladesh for a long time [12]. The research of other authors Vladu and Matis was focused on the perspective of the financial auditors concerning the accuracy of accounting data in Romania. Research has shown that financial auditors who check the fidelity and veracity of financial statements are constantly looking for various methods and ways to help improve the process and increase the objectivity required to assess and express a correctness of accounting reports [13]. Other authors examine effects of creative techniques on the work performed by accountants in the process of preparing financial statements in Nigeria. Their investigation revealed that creative accounting is realized through the manipulation of stock prices, an incorrect amount of reported profit, or incorrect accounting of accounts [14]. Al-Momamani et. al. researched practicing creative principles in Jordan. They found out that the independence and integrity of auditors have a significant impact on their ability to identify the practice of creative accounting [15]. The research of authors Mirdala et al. problem included a questionnaire survey, in which the task was to identify the boundary between positive and negative creative accounting. Based on the results of the questionnaire survey, they found that a large proportion of accountants in the Republic of Serbia are unable to perceive the difference between positive and negative creative techniques [16]. Bhasin examined the impact of creative accounting on managers in Indian companies. To achieve relevant results, he used a questionnaire survey and data from secondary sources, and the results of his research pointed to the use of creative accounting as an attempt to obtain certain benefits that managers can use to achieve more favorable financial information to the outside environment [17]. Nyabuti et. al. highlighted significance of the impact of accounting creativity on financial reporting, with many companies exploiting this impact in a negative light, and thus such abuse was reflected in the collapse of most companies in the environment under study [18]. Peprnickova and Jandova provided an overview of current foreign research on creative accounting in practice over the past five years and an evaluation of using creativity methods in the Czech Republic. The questionnaire survey was focused on accountants, controllers, financial managers, and other financial professions. The results of the survey pointed to the most extensive application, which is the selection of depreciation and valuation methods, the use of estimated items and accruals, leasing, or the provision of loans between related parties. The individual techniques focus more on the items of the income statement and cash flows compared to the balance sheet items [19]. The purpose of the study of the authors Blazek, Durana, and Valaskova Blazek, Durana, and Valaskova applied models in agriculture, forestry, and also fisheries, and found out that an excessive proportion of the companies surveyed practiced creative methods [20]. The author's study, Al-Rawashdeh, acquaints readers with profit management in the environment of commercial banks, which try to achieve the desired results in order to use different accounting means. [21].

\section{CONCLUSION}

In the professional literature, creative accounting is understood as legitimate, which means that it is not illegal to the extent that it does not violate the legislation of the country. Although it is a numbers game that can mislead internal or external users of financial statements, in some cases it can help protect a business from bankruptcy or other adverse conditions. There are many studies and contributions in the literature that explain the issue of creative accounting; we have focused on the above studies. The subject of the mentioned studies in our paper was creative accounting with an emphasis on its origin, tools, motives, or ethical approach, as well as the role of auditors, the method of control and detection of creative accounting, or its impact on financial reporting. Based on individual studies, we can see that creative accounting is used in several countries around the world because each country has its specifics and each company in it is accompanied by different motives for practicing creative accounting. Based on the mentioned studies, these motives may be the achievement of internal goals, the influx of investors, the reduction of the tax liability, and the increase of the market price of shares. The analyzed studies confirm the fact that accounting creativity is present worldwide. It cannot be completely left out of the business environment, but it is possible to try to eliminate it.

\section{ACKNOWLEDGMENTS}

This paper was prepared with the support of VEGA 1/0210/19 Research of innovative attributes of quantitative and qualitative fundaments of the opportunistic earnings modeling which authors gratefully acknowledge.

\section{REFERENCES}

[1] K. Savova, Variable application of accounting standards - current aspects, Ekonomickomanazerske spectrum 15(1) (2021) 111-123.

[2] N. V. Khuong, N. T. Liem, M. T. H. Minh, Earnings management and cash holdings: Evidence from energy firms in Vietnam, Journal of International Studies 13(1) (2020) 247-261. 
DOI: $10.14254 / 2071-8330.2020 / 13-1 / 16$

[3] A. Siekelova, A. Androniceanu, P. Durana, K. Michalikova Frajtova, Earnings Management (EM), initiatives and company size: an empirical study, Acta Polytechnica Hungarica (2020) 17(9)41-56.

[4] J. Grofcikova, Impact of selected determinants of corporate governance on financial performance of companies, Ekonomicko-manazerske spectrum (2020) 14(2) 12-23. DOI: 10.1007/978-3-03038253-7_1

[5] T. Kliestik, K. Valaskova, E. Nica, M. Kovacova,G. Lazaroiu, Advanced methods of earnings management: monotonic trends and change-points under spotlight in the Visegrad countries, Oeconomia Copernicana (2020) 11(2) 371-400.DOI: 10.24136/oc.2020.016

[6] A. S. Al-Delawi, W. M. Ramo, The impact of accounting information system on performance management, Polish Journal of Management Studies (2020) 21(2) 36-48. DOI: 10.17512/pjms.2020.21.2.03

[7] M. Paskaleva, A. Stoykova, Globalization effects on contagion risks in financial markets, Ekonomicko-manazerske spectrum (2021) 15(1)38-54.

DOI: dx.doi.org/10.26552/ems.2021.1.38-54

[8] T. Kliestik, K. Valaskova, G. Lazaroiu, M. Kovacova, J. Vrbka, Remaining Financially Healthy and Competitive: The Role of Financial Predictors, Journal of Competitiveness (2020) 12(1),

74.DOI:https://doi.org/10.7441/joc.2020.01.05

[9] P. Haskins, P. A. G. Lutan, A. Tanase, "Sustainable Value Creation Networks, Digitized Mass Production, and Networked Informationdriven Technologies in Industry 4.0-based Manufacturing Systems," Economics, Management, and Financial Markets (2020) 15(2)37-43. DOI: 10.22381/EMFM15220205

[10] T. Goto, G. Yamamoto, Creative Accounting and Municipal Mergers - A Theoretical and Empirical Approach, OSIPP, Osaka School of International Public Policy, Osaka University, (2018) 1-44. DOI:

http://www.osipp.osak a- u.ac.jp/archives/DP/2018/DP2018E012.pdf

[11]S. Baralexis, Creative accounting in small advancing countries: The Greek case, Managerial Auditing Journal (2004) 19(3) 440-461. DOI: $10.1108 / 02686900410524427$
[12]D. K. Sen, E. L. Inanga, Creative accounting in Bangladesh and global perspectives, In Partners' Conference Program Book, Partners' Conference, Maastricht School of Management, The Netherlands, 2005, pp. 75-87. DOI:

https://citeseerx.ist.psu.edu/viewdoc/download?d $\mathrm{oi}=10.1 \cdot 1 \cdot 613.2900 \& \mathrm{rep}=\mathrm{rep} 1 \&$ type $=\mathrm{pdf}$

A. B. Vladu, D. Matis, Corporate governance and creative accounting: two concepts strongly connected? Some interesting insights highlighted by constructing the internal history of a literature, Annales Universitatis Apulensis Series Oeconomica (2010) 12(1) 332-346.

[13]E. N. Salome, O. M. Ifeanyi, C. M. Ezemoyih, O.E. Echezonachi, The Effect of Creative Accounting on the Job Performance of Accountants (Auditors) in Reporting Financial Statement in Nigeria, Kuwait Chapter of the Arabian Journal of Business and Management Review (2012) 1(9) 1-30.

[14] M. A. Al Momamani, The effect of auditors' ethics on their detection of creative accounting practices: A field study, International Journal of Business and Management (2013) 8(13) 118. DOI: $10.5539 /$ ijbm.v8n13p118

[15] R. Mirdala, V. Mizdrakovic, N. Arežina, D. Stefanovic, Creative accounting: from creativity to misuse, (2014) 1 5-7. DOI: $10.15308 /$ finiz2014-5-7

[16]M. L. Bhasin, Corporate accounting fraud: A case study of Satyam Computers Limited, Open Journal of Accounting (2013) 2(2) 26-38. DOI: http://www. scirp.org/journal/PaperInformation.aspx?paperID $=30220$.

[17] V. Nyabuti, V. M. Ondari, F. Chege, Ch. Njoroge, Influence of creative accounting practices on the financial performance of companies listed in the nairobi securities exchange in Kenya, International Journal of Management and Commerce Innovations (2016) 3(2) 45-59.

[18]M. Peprnickova, L. Jandova, "The Level of Creative Accounting in the Practice of Czech Accounting Entities, Cesky financni a ucetni casopis, Prague University of Economics and Business, 2017(4), pp. 7-86. DOI: 10.18267/j.cfuc.505

[19]R. Blazek, P. Durana, K. Valaskova, Creative Accounting as an Apparatus for Reporting Profits in Agribusiness, Journal Risk Financial 
Management $2020 \quad 13 \quad 261 . \quad$ DOI: $10.3390 / \mathrm{jrfm} 13110261$

[20]A. M. Al-Rawashdeh, The impact of creative accounting methods on financial reports and statements in commercial banks listed on Amman stock exchange (field study) 2021 10(2), pp: 449457.

DOI: 